\title{
Protective effects of quercetin and vitamin $C$ against nicotine-induced toxicity in the blood of Wistar rats
}

\author{
Milica G. Paunović ${ }^{1}$, Branka I. Ognjanovićn ${ }^{1}$ Miloš M. Matić ${ }^{1}$, Andraš Š. Štajn ${ }^{1}$, and \\ Zorica S. Saičić

\begin{abstract}
Faculty of Science, University of Kragujevac, Kragujevac ${ }^{1}$, Department of Physiology, Institute for Biological Research "Siniša Stanković”, University of Belgrade, Belgrade², Serbia
\end{abstract}

[Received in March 2016; CrossChecked in March 2016; Accepted in November 2016]

\begin{abstract}
Nicotine is a potential inducer of oxidative stress, through which it can damage numerous biological molecules. The aim of our study was to investigate the prooxidative effects of nicotine and protective (additive or synergistic) effects of quercetin and vitamin $\mathrm{C}$ in the blood of experimental animals, to determine whether the combination of these antioxidants might be beneficial for clinical purposes. Wistar albino rats were receiving intraperitoneal nicotine injection $\left(0.75 \mathrm{mg} \mathrm{kg}^{-1}\right.$ per day) or saline (control group) or nicotine plus quercetin (40 mg kg-1 per day) and vitamin C (100 mg kg-1 per day) for three consecutive days. On day 4, we determined their blood lipid profile, liver enzymes, oxidative stress parameters, and antioxidative system parameters. Compared to untreated control, nicotine significantly increased total cholesterol, LDLcholesterol, triglycerides, liver enzymes (alanine transaminase, aspartate transaminase, and lactate dehydrogenase) and oxidative stress parameters (superoxide anion, hydrogen peroxide, and lipid peroxide) and decreased HDL-cholesterol, glutathione, and superoxide dismutase/catalase activity. Quercetin + vitamin C reversed these values significantly compared to the nicotine alone group. Our results confirm that nicotine has significant prooxidative effects that may disrupt the redox balance and show that the quercetin + vitamin $\mathrm{C}$ combination supports antioxidant defence mechanisms with strong haematoprotective activity against nicotine-induced toxicity. In practical terms, this means that a diet rich in vitamin $\mathrm{C}$ and quercetin could prevent nicotine-induced toxicity and could also be useful in the supportive care of people exposed to nicotine.
\end{abstract}

KEY WORDS: antioxidant defence; erythrocytes; lipid profile; oxidative damage; reactive oxygen species; tobacco

Nicotine, the primary addictive component of cigarette smoke, is rapidly absorbed by the circulatory system and most of it is metabolised in the liver (1). Previous in vivo studies have shown that chronic use of nicotine disrupts the balance between the prooxidants and antioxidants in the circulation of experimental rats (2). Nicotine triggers the production of free radicals and reactive oxygen species (ROS), including superoxide anion radical $\left(\mathrm{O}_{2}{ }^{\bullet-}\right)$, hydrogen peroxide $\left(\mathrm{H}_{2} \mathrm{O}_{2}\right)$, and hydroxyl radical $\left({ }^{\circ} \mathrm{OH}\right)$, which overwhelm the antioxidative defence system (AOS) and eventually generate oxidative stress (3-6).

Red blood cells are a good indicator of oxidative stress, as their components, haemoglobin and polyunsaturated fatty acids, are susceptible to it (7), which is why they contain antioxidants for efficient defence. These components are non-enzymatic [such as vitamins $\mathrm{C}$ and $\mathrm{E}$, and glutathione $(\mathrm{GSH})$ ] and enzymatic [superoxide dismutase (SOD), catalase (CAT), and glutathione peroxidase (GSH-Px)] (8). The defence system can be improved by the consumption of fruits and vegetables rich in antioxidants, including vitamin $\mathrm{C}$ and flavonoids - polyphenolic compounds common in fruits, vegetables, and some types of tea and wine (9).

Correspondence to: Milica G. Paunović, Institute of Biology and Ecology, Faculty of Science, University of Kragujevac, Radoja Domanovića 12, P.O. Box 60, 34000 Kragujevac, Serbia; E-mail: milicap@kg.ac.rs
One such flavonoid found in abundance in red kidney beans, grapes, red wine, apples, tea, onions, and broccoli is quercetin. Its consumption in everyday diet is too low for a clinically meaningful protective effect but it can easily be increased with quercetin-rich food and supplements (10), whereas its bioavailability increases if consumed with other flavonoids, vitamins C and E, or catechins (11-13).

Considering that Muthukumaran et al. (14) have already demonstrated the antioxidant properties of quercetin alone against nicotine-induced oxidative stress in rats, the aim of our study was to see how effective the combination of quercetin and vitamin $\mathrm{C}$ could be, especially as this combination has never been studied before. By establishing conclusive evidence of the combination's effectiveness against nicotine-induced toxicity, we hoped to see whether this combination could find clinical application. Our secondary aim was to get an insight into the possible underlying mechanisms of (inter)action between nicotine and the combination of antioxidants.

\section{MATERIALS AND METHODS}

\section{Chemicals}

All reagents and chemicals used in this study were of analytical grade or higher purity, obtained from Sigma 
Chemical Co. (St. Louis, MO, USA) and Merck (Darmstadt, Germany). The solutions were prepared with doubledistilled water.

\section{Experimental design}

All the experimental procedures were approved by the University Ethics Committee for Animal Experimentation. We used 18 male albino Wistar rats, about 2 months old, weighing 200-220 g to exclude possible protective effects of oestradiol against provoked oxidative stress $(15,16)$. Before the experiments began, the animals were housed in plastic cages under standard laboratory conditions (temperature $22 \pm 2{ }^{\circ} \mathrm{C} ; 12: 12 \mathrm{~h}$ light:dark cycle) for at least one week to adapt. Tap water and commercial standard rodent laboratory diet were available ad libitum for the duration of the experiments. The rats were randomly divided into three groups ( $n=6$ per group) and treated for three days, as follows: the control group was receiving intraperitoneal (i.p.) injections of isotonic saline $\left[0.1 \mathrm{~mL} \mathrm{~kg}^{-1}\right.$ body weight (b.w.)]; the nicotine group was receiving nicotine only [0.75 $\mathrm{mg} \mathrm{kg}^{-1}$ (b.w.) per day i.p.]; and the nicotine + quercetin + vitamin $\mathrm{C}$ group was receiving nicotine as described above with quercetin [40 $\mathrm{mg} \mathrm{kg}^{-1}$ (b.w.) per day i.p. ] and vitamin C [100 $\mathrm{mg} \mathrm{kg}^{-1}$ (b.w.) per day i.p. ]. These doses were based on literature data $(4,17-21)$ and correspond to the human daily dietary intake of quercetin and vitamin $\mathrm{C}$ enriched food and the daily nicotine intake in people who smoke 10-20 cigarettes per day $(2,4)$.

Twenty-four hours after the last dose, the animals were anaesthetised with ether and decapitated. Blood samples for all analyses were collected on the day of sacrifice between $8 \mathrm{a}$. $\mathrm{m}$. and $10 \mathrm{a}$. $\mathrm{m}$. to avoid variations related to the circadian rhythm.

\section{Analytical procedures}

For the medium we selected rat blood as the best substrate. The blood samples were collected in tubes with anticoagulant (K-EDTA) and without one. Biochemical parameters were measured on the day of sacrifice. Plasma for the other analyses was separated by centrifugation at $1000 \mathrm{~g}\left(+4^{\circ} \mathrm{C}\right)$ for $10 \mathrm{~min}$. The erythrocytes were washed three times with an equal volume of cold saline $(0.9 \%, v / v)$. One millilitre of the washed erythrocytes was lysed with $3 \mathrm{~mL}$ of $\mathrm{dH}_{2} \mathrm{O}(1: 3, v / v)$ at $0{ }^{\circ} \mathrm{C}$ for $30 \mathrm{~min}$. All samples were extracted from the lysates and stored at $-20^{\circ} \mathrm{C}$ for no longer than 7 days. ROS analysis was completed within 1-2 $\mathrm{h}$ after extraction. Lipid peroxides (LPO) and GSH were measured within $6 \mathrm{~h}$ after extraction. Antioxidant enzyme activity in erythrocyte lysate was measured following the method described by McCord and Fridovich (22).

\section{Biochemical analysis}

Blood samples in non-anticoagulant tubes were centrifuged at $1000 \mathrm{~g}\left(+4{ }^{\circ} \mathrm{C}\right)$ for $15 \mathrm{~min}$ to obtain serum for measurements. We analysed the serum for total cholesterol, high-density lipoprotein cholesterol (HDLC), low-density lipoprotein cholesterol (LDLC), triglycerides (TG) (expressed in $\mathrm{mmol} \mathrm{L}^{-1}$ ), and enzyme activity [alanine aminotransferase (ALT), aspartate aminotransferase (AST), and lactate dehydrogenase ( $\mathrm{LDH}$, expressed in $\left.\mathrm{U} \mathrm{L}^{-1}\right)$ ] with a C 8000 Architect autoanalyser (Wiesbaden, Germany) using standard diagnostic colourimetric kits (Abbott Laboratories, Abbott Park, IL, USA).

\section{Oxidative stress parameters}

Erythrocyte ROS concentrations were determined as follows: half the volume of $3 \mathrm{~mol} \mathrm{~L}^{-1}$ perchloric acid and 2 volumes of $20 \mathrm{mmol} \mathrm{L}^{-1}$ EDTA were added to one volume of the lysate. After extraction on ice and centrifugation on $1000 \mathrm{~g}\left(+4{ }^{\circ} \mathrm{C}\right)$ for $10 \mathrm{~min}$, the extracts were neutralised with $2 \mathrm{~mol} \mathrm{~L}^{-1}$ of $\mathrm{K}_{2} \mathrm{CO}_{3}$. The spectrophotometric determination of $\mathrm{O}_{2}{ }^{--}$was based on the reduction of nitroblue tetrazolium in the presence of $\mathrm{O}_{2}{ }^{--}$(23). The determination of $\mathrm{H}_{2} \mathrm{O}_{2}$ was based on the oxidation of phenol red in the presence of horseradish peroxidase as catalyst (24). These concentrations are expressed in $\mu \mathrm{mol} \mathrm{L} \mathrm{L}^{-1}$ of erythrocytes.

Lipid peroxides in the haemolysate were determined using the method described by Ohkawa et al., (25), based on the reaction of lipid peroxidation products (malondialdehydes) with thiobarbituric acid reactive substances (TBARS). Haemolysate samples were extracted with $28 \%$ trichloroacetic acid and centrifuged at $1000 \mathrm{~g}$ for $10 \mathrm{~min}$. For colour reaction we added $1 \%$ TBA and incubated the mixture at $90^{\circ} \mathrm{C}$ for $15 \mathrm{~min}$. The absorbance was measured with a UV/Visible spectrophotometer (Jenway 6105, Bibby Scientific Limited, Staffordshire, UK). These results are expressed in $\mu \mathrm{mol} \mathrm{L}^{-1}$ erythrocytes.

\section{Determination of GSH and antioxidant enzymes}

For GSH determination we used the method of Beutler (26), based on the oxidation of GSH with DTNB (5.5 '-dithiobis-2nitrobenzoic acid). Its concentrations are expressed in $\mu \mathrm{mol} \mathrm{L}^{-1}$ of erythrocytes.

Superoxide dismutase (EC 1.15.1.1) activity was determined using the method described by Marklund and Marklund (27). This method is based on pyrogallol oxidation by $\mathrm{O}_{2}{ }^{--}$and its dismutation by SOD. The enzyme activity is expressed as $\mathrm{U} \mathrm{mL}^{-1}$ of erythrocytes.

For CAT (EC 1.11.1.6) activity measurements we used the method of Beutler (28). The method is based on the rate of $\mathrm{H}_{2} \mathrm{O}_{2}$ degradation mediated by CAT measured spectrophotometrically at $230 \mathrm{~nm}$ in $1 \mathrm{~mol} \mathrm{~L}^{-1}$ Tris- $\mathrm{HCl}$ solution (with $5 \mathrm{mmol} \mathrm{L}^{-1}$ EDTA, pH 8.0). Absorbance was measured with the Jenway $6105 \mathrm{UV} / \mathrm{Visible}$ spectrophotometer and the enzyme activity is expressed in $\mathrm{U} \mathrm{mL}^{-1}$ of erythrocytes. 


\section{Statistical analysis}

All analyses were done using the SPSS for Windows, version 13.0 (SPSS Inc., Chicago, IL, USA). All results are expressed as mean \pm SEM and evaluated using the one-way analysis of variance (ANOVA) test. If there was a significant difference between the groups after applying ANOVA, these groups were compared using Dunnett's multiple comparison tests (control with each treated group). We set statistical significance at $p \leq 0.05$ for all comparisons.

\section{RESULTS AND DISCUSSION}

Our findings have confirmed our expectations based on earlier reports about prooxidative effects of nicotine and the antioxidative effects of quercetin and vitamin C (12-14).

\section{Oxidative stress parameters}

Erythrocyte concentrations of $\mathrm{O}_{2}{ }^{\bullet-}, \mathrm{H}_{2} \mathrm{O}_{2}$, and LPO were significantly higher in the nicotine than control group. Coadministration of quercetin and vitamin $\mathrm{C}$ greatly reversed nicotine-induced changes in these oxidative stress parameters (Figure 1).

These findings confirm earlier conclusions that nicotine exerts its toxic effects through higher ROS production (3-6, 29). In normal conditions, $\mathrm{O}_{2}{ }^{--}$is transformed to $\mathrm{H}_{2} \mathrm{O}_{2}$ by SOD. If its production increases over the SOD buffering capacity, $\mathrm{O}_{2}^{\bullet-}$ can react with $\mathrm{NO}$ to form peroxynitrite $\left(\mathrm{ONOO}^{-}\right)$. Furthermore, in the presence of iron, $\mathrm{O}_{2}{ }^{--}$and $\mathrm{H}_{2} \mathrm{O}_{2}$ can react (Haber-Weiss reaction) to form a highly reactive hydroxyl radical $(\cdot \mathrm{OH})$, which can also be produced by peroxynitrite decomposition. Hydroxyl radicals oxidise polyunsaturated fatty acids in biological membranes and induce the formation of LPO (8). Hence the significantly increased LPO levels in our erythrocytes (Figure 1).

\section{Biochemical test results}

Since increased LPO disrupts the normal function or destroys erythrocyte membranes and causes a leakage of the cytoplasmic marker such as LDH (indicator of cell and tissue damage) into circulation (30), we expected to find elevated values of this parameter as well as enhanced activity of AST and ALT, based on earlier findings in blood and various organs $(14,29,31-34)$. Indeed, treatment with nicotine significantly increased LDH levels and the activities of ALT, AST compared to control (Table 1). Quercetin and vitamin $C$ reversed these changes toward the control ones and minimised the adverse effects of nicotine (Table 1).

Our study has also demonstrated that by interfering with the metabolism of lipoproteins, nicotine causes a significant increase in total cholesterol, LDLC, and TG levels, whereas the level of HDLC significantly drops (Table 2). This is in line with the study by Sharif et al. (33), who have reported adverse nicotine effects on the lipid profile of adult male mice (Mus musculus). Once again, quercetin and vitamin $\mathrm{C}$ co-administration have shown their strong protective effects against nicotine toxicity by restoring lipid levels to near normal values (Table 2)

\section{GSH and antioxidant enzymes}

The nicotine group showed a significant drop in GSH and antioxidant enzyme activities compared to control, and the treatment with quercetin and vitamin $\mathrm{C}$ again reversed these effects (Figure 2).

Table 1 Effects of quercetin and vitamin C on hepatic marker enzyme activities in the serum of nicotine-treated rats (values are expressed as means \pm SEM of 6 animals)

\begin{tabular}{lccc}
\hline \multirow{2}{*}{ Parameters } & \multicolumn{3}{c}{ Experimental groups } \\
\cline { 2 - 4 } & Control & Nicotine & Nicotine + QN + Vit C \\
\hline ALT $\left(\mathrm{U} \mathrm{L}^{-1}\right)$ & $47.5 \pm 1.6$ & $83.2 \pm 2.1^{*}$ & $57.4 \pm 2.2^{* *}$ \\
\hline AST $\left(\mathrm{U} \mathrm{L}^{-1}\right)$ & $148.2 \pm 5.8$ & $184.3 \pm 5.2^{*}$ & $142.6 \pm 4.1^{* *}$ \\
\hline LDH $\left(\mathrm{U} \mathrm{L}^{-1}\right)$ & $625 \pm 22.3$ & $1238 \pm 65.2^{*}$ & $840 \pm 42.3^{* *}$ \\
\hline
\end{tabular}

QN: quercetin; Vit C: vitamin C; ALT: alanine aminotransferase; AST: aspartate aminotransferase; LDH: lactate dehydrogenase. "significantly different from control $(\mathrm{p}<0.05) ;{ }^{*}$ significantly different from nicotine group $(\mathrm{p}<0.05)$

Table 2 Effects of quercetin and vitamin C on lipid profile in the serum of nicotine-treated rats (values are expressed as means $\pm S E M$ of 6 animals)

\begin{tabular}{lccc}
\hline \multirow{2}{*}{ Parameters } & \multicolumn{3}{c}{ Experimental groups } \\
\cline { 2 - 4 } & Control & Nicotine & Nicotine + QN + Vit C \\
\hline TC $\left(\mathrm{mmol} \mathrm{L}^{-1}\right)$ & $1.14 \pm 0.06$ & $1.56 \pm 0.07^{*}$ & $0.95 \pm 0.06^{* *}$ \\
\hline HDLC $\left(\mathrm{mmol} \mathrm{L}^{-1}\right)$ & $0.82 \pm 0.02$ & $0.58 \pm 0.03^{*}$ & $0.86 \pm 0.05^{* *}$ \\
\hline LDLC $\left(\mathrm{mmol} \mathrm{L}^{-1}\right)$ & $0.11 \pm 0.01$ & $0.37 \pm 0.03^{*}$ & $0.20 \pm 0.03^{* *}$ \\
\hline TG $\left(\mathrm{mmol} \mathrm{L}^{-1}\right)$ & $0.18 \pm 0.02$ & $0.41 \pm 0.04^{*}$ & $0.24 \pm 0.05^{* *}$ \\
\hline
\end{tabular}

QN: quercetin; Vit C: vitamin C; TC: total cholesterol; HDLC: high density lipoprotein cholesterol; LDLC: low density lipoprotein cholesterol; TG: triglicerides. "significantly different from control ( $<<0.05)$; ${ }^{* *}$ significantly different from nicotine group $(\mathrm{p}<0.05)$ 

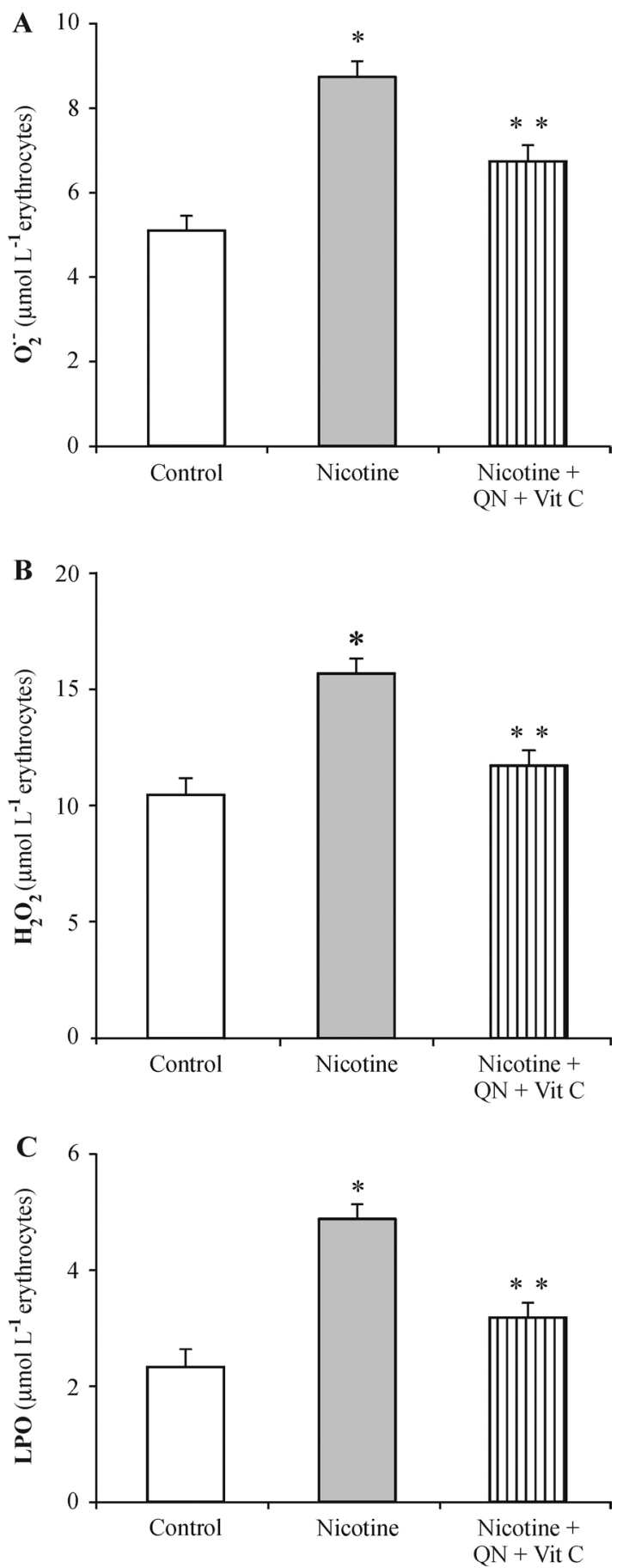

Figure 1 Effects of quercetin and vitamin $C$ on oxidative stress parameters $\left(\mathrm{O}_{2}^{\bullet}, \mathrm{H}_{2} \mathrm{O}\right.$, and $\left.L P O\right)$ in the blood of nicotine-treated rats (values are expressed as means \pm SEM of 6 animals). $Q N$ : quercetin; Vit $\mathrm{C}$ : vitamin $\mathrm{C} ; \mathrm{O}_{2}^{\bullet-}$ : superoxide anion radical; $\mathrm{H}_{2} \mathrm{O}_{2}$ : hydrogen peroxide; LPO: lipid peroxides. *significantly different from control $(\mathrm{p}<0.05) ;{ }^{* *}$ significantly different from nicotine group $(\mathrm{p}<0.05)$
The decreased levels of GSH in nicotine-treated rats indicate that GSH protects membrane lipids from oxidation by scavenging free radicals, passing from reduced to oxidized form (GSSG) $(14,31,35)$. Oxidative stress in erythrocytes induced by nicotine can inactivate SOD and CAT proteins or affect their synthesis de novo, which consequently reduces their activity. Lower SOD activity is due to its reaction with $\mathrm{O}_{2}{ }^{--}$to form $\mathrm{H}_{2} \mathrm{O}_{2}$ and $\mathrm{O}_{2}$. $\mathrm{H}_{2} \mathrm{O}_{2}$ is also a substrate for CAT, whose role is to degrade $\mathrm{H}_{2} \mathrm{O}_{2}$ into $\mathrm{H}_{2} \mathrm{O}$ and $\mathrm{O}_{2}(8)$, thereby decreasing its activity as we observed in our study. Other studies $(31,35)$ have also demonstrated the depletion of SOD and CAT in some organs of nicotine-treated rats.

As for the protective effects of the quercetin plus vitamin $\mathrm{C}$ combination, they seem to protect phospholipid bilayers by non-covalent bonding, enhancing this way the regeneration of endogenous antioxidants (12). Our results confirm the protective effects of quercetin and vitamin $\mathrm{C}$ against nicotine-induced changes in both enzymatic and non-enzymatic antioxidants due to either direct scavenging of ROS or induction of antioxidant enzymes.

There are some limitations to our study: the protective effects of the quercetin plus vitamin $\mathrm{C}$ combination was evaluated against nicotine alone, as only one of the many components of tobacco. Therefore, our findings can not be interpreted as simply as to claim that quercetin plus vitamin $\mathrm{C}$ would provide the same level of protection against tobacco products in general. Furthermore, we have not compared the protective effects of this combination with quercetin alone, which would probably give a better insight into the mechanisms of their interaction (additive or synergistic). In addition, further research should look into the effects of higher quercetin doses and whether these effects may become prooxidant, as suggested by Heeba and Mahmoud (36). Future research should also be able to elucidate the exact molecular mechanisms of quercetin and vitamin $\mathrm{C}$ protection against nicotine or other alkaloids and drugs.

Our findings, however, have practical implications. The combination of quercetin and vitamin $\mathrm{C}$ in the selected doses (40 $\mathrm{mg} \mathrm{kg}^{-1}$ b.w. and $100 \mathrm{mg} \mathrm{kg}^{-1}$ b.w., respectively) seems to sufficiently reinforce the antioxidative defences and diminish the adverse effects of nicotine for us to recommend the adapted doses in persons exposed to nicotine, tobacco smokers in particular.

\section{Conflict of interest}

The authors declared that there are no conflicts of interest.

\section{Acknowledgements}

This study was supported by the Ministry of Education, Science and Technological Development of Republic of Serbia, grant no. 173041. 

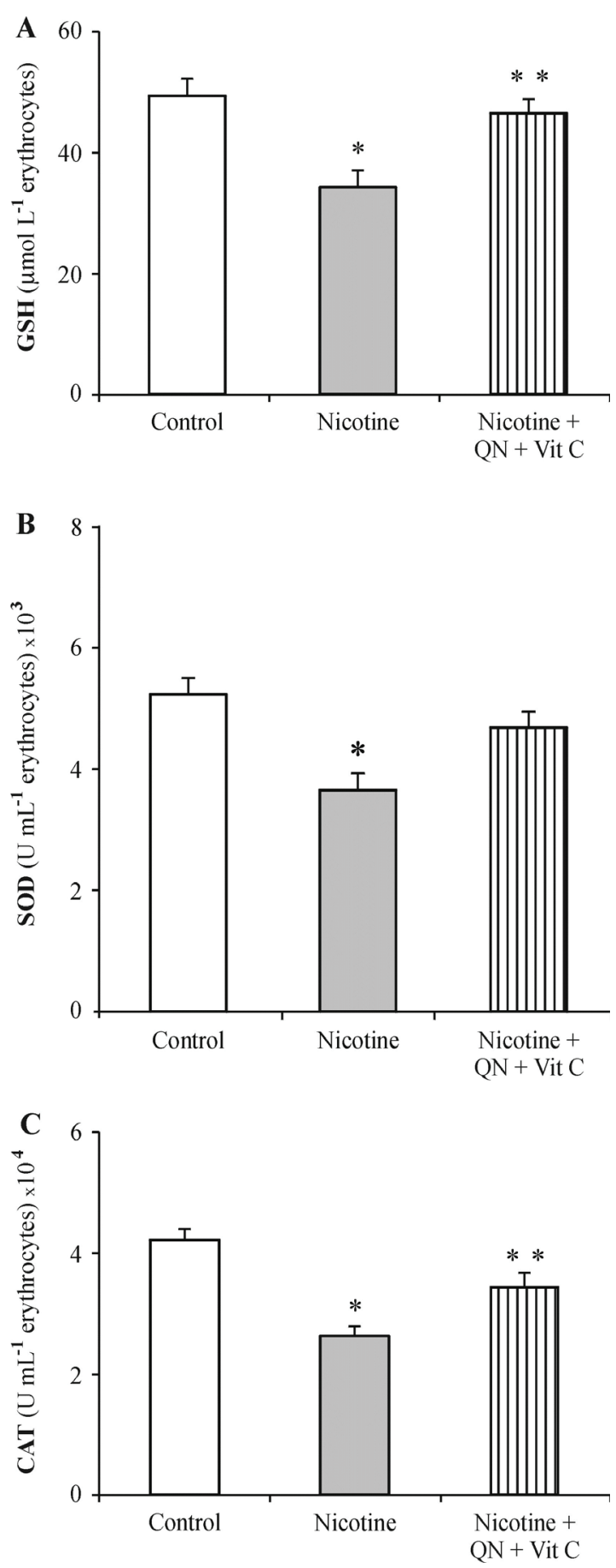

Figure 2 Effects of quercetin and vitamin $C$ on the antioxidative defense system (GSH, SOD, and CAT) in the blood of nicotinetreated rats (values are expressed as means $\pm S E M$ of 6 animals). QN: quercetin; Vit C: vitamin C; GSH: reduced glutathione; SOD: superoxide dismutase; CAT: catalase. * significantly different from control $(\mathrm{p}<0.05) ; * *$ significantly different from nicotine group $(\mathrm{p}<0.05)$

\section{REFERENCES}

1. Omar NAA, Allithy ANEA, Faleh FM, Mariah RA, Ayat MMA, Shafik SR, Elshweikh SA, Baghdadi H, El Sayed SM. Apple Cider Vinegar (A Prophetic Medicine Remedy) Protects against Nicotine Hepatotoxicity: A Histopathological and Biochemical Report. AJCP 2015;3:122-7. doi: 10.12691/ajcp-3-6-4

2. Jain A, Flora SJS. Dose related effects of nicotine on oxidative injury in young, adult and old rats. J Environ Biol 2012;33:233-8. PMID: 23033686

3. Mosbah R, Yousef MI, Mantovani A. Nicotine-induced reproductive toxicity, oxidative damage, histological changes and haematotoxicity in male rats: the protective effects of green tea extract. Exp Toxicol Pathol 2015;67:253-9. doi: 10.1016/j.etp.2015.01.001.

4. Ahmed MA, Hassan KH, Hassanein KM, Waly H. Role of vitamin $\mathrm{C}$ and selenium in attenuation of nicotine induced oxidative stress, P53 and Bcl 2 expression in adult rat spleen. Pathophysiology 2014;21:211-7. doi: 10.1016/j. pathophys.2014.07.003.

5. Li Y, Yu C, Shen G, Li G, Shen J, Xu Y, Gong J. Sirt3MnSOD axis represses nicotine-induced mitochondrial oxidative stress and mtDNAdamage in osteoblasts. Acta Biochim Biophys Sin 2015;47:306-12. doi: 10.1093/abbs/ gmv013.

6. Pamplona R, Costantini D. Molecular and structural antioxidant defenses against oxidative stress in animals. Am J Physiol Regul Integr Comp Physiol 2011;301:84363. doi: 10.1152/ajpregu.00034.2011.

7. Krishnamoorthy VK, Rather IA. Protective effect of Embilica officinalis (amla) on metal-induced lipid peroxidation in human erythrocytes. Pak J Pharm Sci 2016;29:1023-6. PMID: 27383481

8. Pisoschi AM, Pop A. The role of antioxidants in the chemistry of oxidative stress: A review. Eur J Med Chem 2015;97:55-74. doi: 10.1016/j.ejmech.2015.04.040.

9. Procházková $\mathrm{D}$, Boušová I, Wilhelmová N. Antioxidant and prooxidant properties of flavonoids. Fitoterapia 2011;82:513-23. doi: 10.1016/j.fitote.2011.01.018.

10. Li Y, Yao J, Han C, Yang J, Chaudhry MT, Wang S, Liu $\mathrm{H}$, Yin Y. Quercetin, Inflammation and Immunity. Nutrients. 2016;8:167. doi: 10.3390/nu8030167.

11. Askari G, Hajishafiee M, Ghiasvand R, Hariri M, Darvishi L, Ghassemi S, Iraj B, Hovespian V. Quercetin and vitamin C supplementation: effects on lipid profile and muscle damage in meleathletes. Int J Prev Med 2013;4:58-62. PMID: 23717772

12. Fabre G, Bayach I, Berka K, Paloncýová M, Starok M, Rossi C, Duroux JL, Otyepka M, Trouillas P. Synergism of antioxidant action of vitamins $\mathrm{E}, \mathrm{C}$ and quercetin is related to formation of molecular associations in biomembranes. Chem Commun (Camb) 2015;51:7713-6. doi: $10.1039 / \mathrm{c} 5 \mathrm{cc} 00636 \mathrm{~h}$.

13. McAnulty SR, Nieman DC, McAnulty LS, Lynch WS, Jin F, Henson DA. Effect of mixed flavonoids, n-3 fatty acids, and vitamin $\mathrm{C}$ on oxidative stress and antioxidant capacity before and after intense cycling. Int J Sport Nutr Exerc Metab 2011;21:328-37. PMID: 21813916

14. Muthukumaran S, Sudheer AR, Menon VP, Nalini N. Protective effect of quercetin on nicotine-induced prooxidant and antioxidant imbalance and DNA damage 
in Wistar rats. Toxicology 2008;243:207-15. PMID: 18045763

15. Halima BA, Sarra K, Kais R, Salwa E, Najoua G. Indicators of oxidative stress in weanling and pubertal rats following exposure to nicotine via milk. Hum Exp Toxicol 2010;29:489-96. doi: 10.1177/0960327109354440.

16. Mladenović J, Ognjanović B, Đorđević N, Matić M, Knežević V, Stajn A, Saičić Z. Protective effects of oestradiol against cadmium-induced changes in blood parameters and oxidative damage in rats. Arh Hig Rada Toksikol 2014;65:37-46. doi: 10.2478/10004-1254-652014-2405.

17. Harwood M, Danielewska-Nikiel B, Borzelleca JF, Flamm GW, Williams GM, Lines TC. A critical review of the data related to the safety of quercetin and lack of evidence of in vivo toxicity, including lack of genotoxic/carcinogenic properties. Food Chem Toxicol 2007;45:2179-205. PMID: 17698276

18. Dong YS, Wang JL, Feng DY, Qin HZ, Wen H, Yin ZM, Gao GD, Li C. Protective effect of quercetin against oxidative stress and brain edema in an experimental rat model of subarachnoid hemorrhage. Int J Med Sci 2014;11:282-90. doi: 10.7150/ijms. 7634.

19. Zheng J, Wu J, Chen J, Liu J, Lu Y, Huang C, Hu G, Wang $\mathrm{X}$, Zeng Y. Therapeutic effects of quercetin on early inflammation in hypertriglyceridemia-related acute pancreatitis and its mechanism. Pancreatology 2016;16:200-10. doi: 10.1016/j.pan.2016.01.005.

20. Mladenović J, Paunović M, Matić M, Knežević V, Ognjanović B, Štajn A, Saičić Z. Copper-induced changes of lipid peroxidation and hemato-biochemical parameters in rat blood: Protective role of flavonoids. Arch Bio Sci 2014;66:1271-1279. doi: 10.2298/ABS1403271M

21. Oudemans-van Straaten HM, Spoelstra-de Man AM, de Waard MC. Vitamin C revisited. Crit Care 2014;18460. doi: 10.1186/s13054-014-0460-x.

22. McCord JM, Fridovich I. Superoxide dismutase: an enzymic function for erythrocuprein (hemocuprein). J Biol Chem 1969;244:6049-55. PMID: 5389100

23. Auclair C, Voisin E. Nitroblue tetrazolium reduction. In: Greenwald RA editor. CRC Handbook of methods for oxygen radical research. Florida: CRC Press, Boca Raton; 1985. p. 123-32.

24. Pick E, Keisari Y. A simple colorimetric method for the measurement of hydrogen peroxide produced by cells in culture. J Immunol Methods 1980;38:161-70. PMID: 6778929
25. Ohkawa H, Okishi N, Yagi K. Assay for lipid peroxides in animal tissues by thiobarbituric acid reaction. Anal Biochem 1979;95:351-8. PMID: 36810

26. Beutler E. Reduced glutathione (GSH). In: Beutler E editor. Red cell metabolism, a manual of biochemical methods. New York: Grune and Straton; 1975. p. 112-4.

27. Marklund S, Marklund G. Involvement of superoxide anion radical in the autoxidation of pyrogallol and a constituent assay for superoxide dismutase. Eur J Biochem 1974;47:469-79. PMID: 4215654

28. Beutler E. Catalase. In: Beutler E editor. Red cell metabolism, a manual of biochemical methods. New York: Grune and Straton; 1982. p. 105-16.

29. Jain A, Dwivedi N, Bhargava R, Flora SJS. Silymarin and naringenin protects nicotine induced oxidative stress in young rats. Oxid Antioxid Med Sci 2012;1:41-49.

30. Stark G. Functional consequences of oxidative membrane damage. J Membr Biol 2005;205:1-16. PMID: 16245038

31. Al-Malki AL, Moselhy SS. Protective effect of vitamin E and epicatechin against nicotine-induced oxidative stress in rats. Toxicol Ind Health 2013;29:202-8. doi: $10.1177 / 0748233711430976$.

32. Dhouib H, Jallouli M, Draief M, El-Fazaa S, Bouraoui S. The Effect of Nicotine and its Interaction with Ethanol on Biochemical Parameters, Oxidative Damage and Histological Changes in the Rat's Liver. IOSR-JESTFT 2014;8:72-82.

33. Sharif S, Farasat T, Fatima N, Farooq A, Naz S. Effect of Nicotine on Hematology, Lipid Profile and Liver Enzymes in Adult Male Mice (Mus musculus). Adv Anim Vet Sci $2014 ; 2: 222-5$. DOI: $10.14737 /$ journal. aavs/2014/2.4.222.225

34. Chelland Campbell S, Moffatt RJ, Stamford BA. Smoking and smoking cessation - the relationship between cardiovascular disease and lipoprotein metabolism: a review. Atherosclerosis 2008;201:225-35. PMID: 18565528

35. Simeonova R, Vitcheva V, Gorneva G, Mitcheva M. Effects of myosmine on antioxidative defence in rat liver. Arh Hig Rada Toksikol 2012;63:7-14. doi: 10.2478/100041254-63-2012-2190

36. Heeba GH, Mahmoud ME. Dual effects of quercetin in doxorubicin-induced nephrotoxicity in rats and its modulation of the cytotoxic activity of doxorubicin on human carcinoma cells. Environ Toxicol 2016;31:624-36. doi: $10.1002 /$ tox. 22075 


\section{Zaštitno djelovanje kvercetina i vitamina C protiv nikotinom izazvane toksičnosti u krvi Wistar štakora}

Nikotin je potencijalni induktor oksidacijskoga stresa, preko kojega može oštetiti brojne biološke molekule. Cilj našega istraživanja bio je ispitati prooksidacijsko djelovanje nikotina i zaštitno (aditivno ili sinergističko) djelovanje kvercetina i vitamina $\mathrm{C}$ u krvi eksperimentalnih životinja te utvrditi može li kombinacija tih antioksidansa biti korisna u kliničke svrhe. Wistar albino štakori primali su intraperitonealno injekciju nikotina $\left(0,75 \mathrm{mg} \mathrm{kg}^{-1}\right.$ po danu) ili fiziološke otopine (kontrolna skupina) ili nikotina s kvercetinom $\left(40 \mathrm{mg} \mathrm{kg}^{-1}\right.$ po danu) i vitaminom C (100 mg kg-1 po danu) tri uzastopna dana. Četvrtoga dana odredili smo lipidni profil u krvi, jetrene enzime, parametre oksidacijskoga stresa i antioksidacijskoga sustava. U usporedbi s netretiranom kontrolnom skupinom, nikotin je značajno povećao ukupni kolesterol, LDL-kolesterol, trigliceride, jetrene enzime (alanin transaminaze, aspartat transaminaze i laktat dehidrogenaze) i parametre oksidacijskoga stresa (superoksid anion, vodikov peroksid i lipidne perokside), a smanjio HDL-kolesterol, glutation i aktivnosti superoksid dismutaze/katalaze. Kvercetin i vitamin C značajno su utjecali na te vrijednosti u odnosu na skupinu samo s nikotinom. Naši rezultati potvrdili su značajno prooksidacijsko djelovanje nikotina koje može poremetiti redoks ravnotežu i pokazuje da kombinacija kvercetina i vitamina $\mathrm{C}$ podržava antioksidacijske obrambene mehanizme s jakim hematoprotekcijskim aktivnostima protiv nikotinom izazvane toksičnosti. Možemo zaključiti da prehrana bogata kvercetinom i vitaminom $\mathrm{C}$ može koristiti kao prevencija nikotinom inducirane toksičnosti te da kombinacija tih dvaju antioksidansa može biti korisna u kliničkom oporavku ljudi izloženih nikotinu.

KLJUČNE RIJEČI: antioksidacijska obrana; duhan; eritrociti; lipidni profil; oksidacijska oštećenja; reaktivne vrste kisika 